\title{
Lechachenko T. \\ ANALYSIS OF FOREIGN EXPERIENCE OF IMPLEMENTATION OF THE DUAL FORM OF EDUCATION AND ACCESSIBILITY OF ITS IMPLEMENTATION IN UKRAINE
}

Об’єктом дослідження є закордонний досвід дуальної форми навчання. Одним із найбільш проблемних місць є ефективне перенесення дуальної форми навчання у країни із відсутністю досвіду впровадження та функціонування даного типу навчання. Складність перенесення дуального навчання полягає у багатолітньому формуванні моделі у країнах зародження. Характерні риси моделей дуального навчання були набуті в результаті впливу місцевих чинників та умов країн зародження. Складність перенесення також полягає у формалізащії даних ощінки потенціалу країни впровадження. Для вирішення даної задачі найкраще підходять методи нечіткої логіки. Перевагою використання апарату нечіткої логіки є можливість формалізаиї даних складних систем, конвертування якісних показників у кількісні та навпаки. У дослідженні використано метод нечіткого виведення програмного середовища Matlab.

У даній роботі був проведений аналіз передумов впровадження дуальної освіти в Україні. Здійснено аналіз закордонного досвіду дуального навчання. В результаті, були виділені та згруповані у три підсистеми (економічну, політичну та культурно-освітню) фактори для здійснення оцінки потенщіалу впровадження дуальної освіти в Україні.

Результати моделювання, показані у дослідженні, дають відповідь на питання доцільності реалізаціі дуальної форми освіти та оцінки даного потенціалу України. Дані, отримані в результаті моделювання, свідчать про дочільність впровадження дуального навчання в Україні. Це пов'язано із тим, що метод нечіткого моделювання показав належність інтегральної очінки до середнього терму виведення. Серед позитивних чинників, що вплинули на даний результат варто відмітити рівень витрат держави ВВП на освіту та рівень престижу професійної освіти.

Перевагою дослідження є кількісна оцінка потенціалу трансферу дуальної форми навчання в Україні, що важливо також із точки зору міжнародного дискурсу трансферу дуальної форми навчання. У роботі формалізовано модель потенціалу країни впровадження дуального навчання.

Ключові слова: Әуальна освіта, професійне навчання, нечітка логіка, інтегрована оцінка, система нечіткого виведення.

Received date: 27.11 .2018

Accepted date: 20.12 .2018

Published date: 30.06 .2019
Copyright (C) 2019, Lechachenko T. This is an open access article under the CC BY license (http://creativecommons.org/licenses/by/4.0)

\section{Introduction}

The political direction of the development of Ukraine is due to the ratification on September 16, 2014 by the Verkhovna Rada of Ukraine and the European Parliament of the Association Agreement between Ukraine and the European Union (EU). The principles of the agreement provide for the gradual economic integration of Ukraine with the EU. The result of economic integration is the process of raising the standards of Ukrainian products and services to the European level. Updating production and business processes, fixed assets of enterprises will require financial investments. The success of economic transformation depends on many factors. The main capital in any company is human. Among the complex aspects of investing, it is worth noting that the most successful and innovative companies invest in human capital, including in the development of their own personnel. Since the constant recruitment of new professional personnel, their adaptation and further education cost the company significant financial and time costs.
In addition to the declared direction of development of Ukraine, it should be noted the trend of the world economy, in particular the digitalization of industrial production. So, in 2011 at the industrial exhibition in Hanover, the term «Industry 4.0» first appeared [1]. The concept of Industry 4.0 is related to such concepts as «cyber-physical systems» and «Internet of things».

The innovative development in the direction of the industry of the future was declared by France, China in the initiative «made in China 2025», Model of reference architecture for Industry 4.0 was developed to solve the standardization problem in Germany [1]. Ukraine also approved the concept of the development of the digital economy and society for 2018-2020. In which, among other things, it is noted that the integration of digital technologies in production processes or the digitalization of industry is a priority of state industrial policy [2].

Thus, the synchronization of the development direction of the Ukrainian economy with the trend of highly developed economic countries is the key to progressive 
changes. However, as already noted, the main capital in any economic system is workers. The basis for successful economic development of the country is the quality and system of vocational education. As a result of rapid economic transformations, the emergence of new technologies, and the change in the paradigm of industrial development itself, one can observe some weakening of the connection between state educational institutions and the labor market. The restoration of communication between educational institutions and subjects of market relations lies in the plane of integration of stakeholders at the stage of education of professional personnel. In contrast to the relations of consumption of the final result, the subjects of market relations in Ukraine should become an interested party in the field of education of future workers, thereby investing in their own development, according to the concept of stakeholders. The implementation of an integrated form of cooperation is a dual form of education. The dual form of education is the basis of the industrial development of such highly developed countries as Germany and Switzerland. The functioning of dual education in the countries of its implementation eliminates a significant drawback that is inherent in the educational sphere, in particular, the presence of lags. That is, delays between updating educational programs, professional competencies, qualifications, education equipment and current market development. The absence of this shortcoming contributes to continuous economic development and growth in countries with dual education. Due to the direct connection between industry and education, the two systems function as complementary, achieving a synergistic effect from the interaction.

Therefore, it is relevant to study the feasibility of introducing dual education in Ukraine at this stage of its development. The educational sector needs to be reformed by restoring the connection of the educational system with the labor market and the economy through the introduction of a dual form of education. Since the decline in the quality of education of specialists, the discrepancy between the acquired competencies and the requirements of employers, the high level of unemployment among graduates and imbalances in the labor market are the reasons for educational reform.

\section{The object of research and its technological audit}

The object of research is the foreign experience of the dual form of education. The dual form of education is a combination of education in the workplace and in an educational institution, usually on a contract basis. The dual form of education has a long tradition of functioning in such European countries as Germany, Switzerland, Austria. There is no single reference model for the dual form of education. This fact is due to the fact that dual education is a system that is integrated into the national functioning environment. The formation and development of dual education in each country is different. As a result, the system acquires individualized rice of the national functioning model. The formation of the system is influenced by various national factors. The development and development of dual learning is determined by the stakeholders of the process. Among the main stakeholders can be identified organizations of trade unions, employers, educational institutions. The dominant side of the interac- tion determines the functioning model of dual education. The state in the process of dialogue of stakeholders acts as a guarantor of ensuring the vital functions of the system takes into account the interests of stakeholders.

The disadvantages of the functioning of dual education include the dependence of the system on crisis phenomena in the economy. That is, the offer of apprenticeship places depends on the companies that provide. During the crisis period, companies reduce the number of education places, as a result, the state must take measures to restore the balance of supply. In addition, there is the problem of reducing the demand for education places in a dual form. Another problematic aspect can be attributed to the requirements of trade unions and employers' organizations for the quality and content of education, student pay, and examinations. Thus, the analysis of state measures and the factors that influence the offer of apprenticeship places is important not only for restoring the balance of places, but also for introducing dual education as such.

\section{The aim and objectives of research}

The aim of research is analysis of the possibility of implementing dual education in Ukraine. As a result, it is necessary to solve the following objectives:

1. To determine the prerequisites for the introduction of dual education in Ukraine.

2. To make an analysis of foreign practices in the functioning of this type of education.

3. To formalize a model of fuzzy inference of potential assessment.

4. To assess on the basis of the existing model of the potential for the introduction of dual education in Ukraine by deriving an integrated assessment followed by an analysis of the constituent indicators.

\section{Research of existing solutions of the problem}

The dual form of education is new to the Ukrainian educational system. The long history of the formation and development of dual education in such European countries as Germany Austria, Switzerland determines the application of an integrated approach to the study and application of the system in new countries of implementation. The history of formation and the problem of the cooperation of stakeholders of dual education in Germany are covered in [3]. The history of the development of the German model of dual education reveals the dominance of companies in the model and the lack of cooperation between companies and schools. The evolution of institutional changes from collectivism to segmentalism and the modernization of German dual education are described in $[4,5]$. In particular, it is important to highlight the institutional models of dual education based on the wide and narrow competence of education specialists for its transferability. The challenges of the Swiss vocational education system are highlighted in [6]. The advantages and problems of the implementation of professional and dual education, its functioning in individual countries, in particular, are highlighted in [7]. In [8], 11 elements of the dual system are identified, which should be taken into account when transferring the dual learning model to new countries. In particular, let's consider such an element as the social acceptability of 
vocational education in the recipient country, the impact of taxation of companies in South Korea on the offer of apprenticeship places [8]. The transfer of the Austrian model of dual education to developing countries is analyzed in [9]. In particular, this work notes the absence in the target countries (implementation of the dual system) of a typical Austrian institutional environment of dialogue among stakeholders based on a basic social contract. As well as the weakness or absence in the target countries of associations of employers, trade unions, representatives of employers, employment services and the labor market. In [10], the introduction of dual learning in Hungary is considered, in the model of which a company subsidization system is used to stimulate companies.

Given the novelty of the topic, the problem of the appropriateness of introducing dual learning and the analysis of the necessary model is not sufficiently covered in the Ukrainian scientific discourse. Since Ukraine is at the stage of introducing dual education [11], there is therefore a need to analyze the problem in a scientific branch.

The problem of transferring dual education to the countries of implementation is due to the long history of the formation of this type of education, the formation of which has acquired individual characteristics. As a result, national models of dual education in European countries are distinguished by a peculiar system inherent only in this country due to the specific local circumstances of the formation. Thus, the problem of introducing dual education in new circumstances requires the study of local conditions of vocational education, economic, cultural and political factors. The long-term functioning of dual education (apprenticeship) in a number of European countries reveals the factors that influence the implementation through the analysis of methods for regulating the number of apprenticeship places in companies during crisis periods. Depending on the socio-economic circumstances of countries and the culture of companies investing in human capital, the implementation climate may differ. In particular, the reasons for investing and refusing to invest in the apprenticeship of companies are considered in [12]. In [13], the reasons for investing in general education firms are disclosed, which can be explained by the imperfection of the labor market and the importance of its institutions, their impact on the structure of wages. In particular, the study emphasizes the greater willingness of firms to invest in education with a low level of staff turnover, which is associated with the imperfection of the labor market due to the protection of employment.

So, the foreign experience in the functioning of dual education reveals the factors affecting the functioning of the system and stimulating companies to provide places for apprenticeships. It is worth noting the absence of examples of a comprehensive quantitative study of assessing the potential for introducing dual education in new implementation countries. The literature in question makes it possible to form this research model.

\section{Methods of research}

In the process of conducting the research, the following scientific methods were used:

- analysis method that is used to study the prerequisites for the introduction of dual education in Ukraine, the study of literary sources to establish forms of interaction in the dual education model of its structure, factors of influence on the implementation and functioning of the system;

- method of a systematic approach that is used in the process of grouping factors of influence on assessing the potential for introducing dual education;

- modeling method that is used in formalizing the model of fuzzy inference and obtaining on this basis the results of an integrated assessment.

\section{Research results}

6.1. Foreign experience of dual education. The need to implement the dual form of education in Ukraine is due to the need to achieve sustainable economic growth through overcoming a number of problems that are inherent in the Ukrainian educational sphere. Such problems include: poor quality of graduate education, the gap between theory and practice of education, outdated equipment of educational institutions, the imbalance between demand and supply in the labor market.

The dual form of education is characterized by a combination of education at the workplace and in the educational institution on a contract basis with the predominance of education in the company. The evolution of formation and the characteristic features of dual learning inherent in individual countries of its functioning reveal the complexity of the formation of such learning. Given the complexity of the concept of dual learning, the functioning of which is provided at different levels of cooperation between stakeholders, as well as its socio-economic significance, this definition needs to be clarified.

The dual form of education is a education system, the implementation of which occurs through activities in the workplace. The constituent subsystems of this form of education are education in a company (work environment) and in an educational institution, in which the connection between learning locations is fundamentally ensured by information technology. The purpose of the dual form of education is in providing students with the necessary competencies and qualifications with a high probability of further employment.

It is worth noting that the dual form of education can be classified as a cybernetic system that achieves a synergistic effect from the interaction of education subsystems, the difficulty of managing which is to maintain a balance of interests of stakeholders.

To analyze practices and the possibility of implementing dual education in Ukraine, it is necessary to understand the history of its emergence and formation. The term dual education was first used in 1964 in a report by the German Committee for Education. This fact was preceded by a long history of the formation of the model of apprenticeship. It should be noted that apprenticeship in Europe existed from the early Middle Ages to the 20th century, based on pure education in the company and focused on the craft model guided by guilds. A characteristic feature of the establishment of dual education in Germany is the direction of the distribution of education, from the sole education of companies to co-education with vocational schools. In this formation of dual education in Germany, the role of the state should be noted. At first, the control of guilds over apprenticeship was legally abolished in 1871, and subsequently restored in 1881 and 1897 with the 
establishment of the Chamber of Crafts, an intermediary between state regulation and autonomy of the apprenticeship guilds that were part of the chamber. The prototype of dual education began to take shape from 1881 to 1919 with the legislative introduction of compulsory school attendance for students studying in the company. Further legislative consolidation of compulsory school attendance for internal education took place during the time of $\mathrm{Na}$ tional Socialist rule [3].

This introspection of the emergence of dual education in Germany illustrates the influence of the state, both on internal education at the time of the guilds and the appearance of compulsory education in vocational schools. The culture of apprenticeship in Germany is a phenomenon that has been cultivated for decades. The formation of apprenticeship should be considered as a component of the economic strategy, therefore its success depends on the degree of state involvement in this process. The dominant role in the German dual education system belongs to companies. This is expressed by the fact that the responsibility for preparing students lies with enterprises. The balance of state regulation of German dual education was built on the already existing strong system of in-house education. Confirmation of this fact is an amendment to the 2005 Vocational Education Act regarding the strengthening of the role of professional schools in the preparation of students in dual education, which are legislatively fixed, but are not actually used in practice [3].

Depending on state regulation, there are three systems for organizing vocational education [14]:

1) market model;

2) state control model;

3) cooperative model.

An example of the functioning of the market model is the United Kingdom, in which in-house education depends on the demand of companies. Such a model is characterized by insignificant direct state intervention in apprenticeship policy. The offer of apprenticeship places depends on the needs of companies, the narrow specialization of students is determined by the content of education, which is limited by the tasks and goals of the companies. As a result, the supply of apprenticeship places is sensitive to economic crises.

In the model of state control of the vocational education system, content, regulation and administrative management is carried out by the state. The model does not depend on the availability of education places in the company. The correlation between supply and demand in the market is not proportional, since the qualifications obtained are not necessary for the labor market. Vocational education in this model is an integral part of general education. An example of the functioning of such a model is France. It is worth noting that Ukraine can also be attributed to this model.

The cooperative model includes countries with a strong apprenticeship system. The model is based on the dual form of education. The cooperative model provides for advanced qualifications as opposed to a market one. Complexity of qualifications is achieved through standardization of education in companies and visits to vocational schools. The influence of the state is mediated by cooperative bodies of cooperation, through which influence and control on the vocational education system are carried out. Germany, Denmark, Switzerland, Austria are countries that have such a vocational education system.
The dual system is present in the cooperative model of vocational education. The effectiveness of dual education in its countries of presence is sensitive to fluctuations in the labor market and, as a consequence, economic crises. Restoring equilibrium involves government intervention through its mandate in the organizational structures of trilateral cooperation (employers, trade unions, and government officials). According to the state policy of regulating dual education, one can distinguish segmentarism and collectivism [4]. Segmentarism is present in liberal economies with minimal regulation and standardization of education in companies. Collectivism pursues the task of personnel education «beyond need». It should be noted that unions play a different role in the dominance of various systems. In a system of segmentation, unions rely on social partnerships within the firm, as well as between large companies. The collective system provides for union partnerships at the national level. Despite its goals, the system leans on the support of the state in the issue of coordination and compliance with advanced qualifications [4].

Collective and segmental systems against the background of the economic situation can dominate for a certain period in countries with a developed dual education system. The reasons for the predominance of a certain type of system are rooted in political goals that aim to stabilize the supply of apprenticeship places from companies. In fact, such events take place with the already established system of in-company education. In this context, an important issue is the analysis of the transition of the vocational education system from education in professional institutions to the dual form in the country of use. Instilling a dual education system in countries with no such experience is problematic. Existing examples of system transfer demonstrate a small number of students involved in this form.

6.2. Formalization of the model of fuzzy inference of the assessment of the country potential implementing dual education. The introduction of the dual form of education occurs through the integration of the dual system in the country's environment with well-established socio-economic ties between various institutions. Moreover, the functioning of the transplanted system depends on the market environment of the country. The complexity of the relationships between various stakeholders is determined by the use of the characteristic mathematical apparatus for their assessment. The ability to convert qualitative estimates into quantitative and their integrated accounting in the model is an advantage of using the fuzzy logic apparatus.

In 1965, work [15] laid the foundation for the development of the theory of fuzzy sets and fuzzy logic, the mathematical apparatus of which, in particular, allows to formalize complex socio-economic systems.

The central concept in fuzzy sets and fuzzy logic is a membership function. This function reflects the degree of belonging in the interval $[0,1]$ of each element $u$ of the universal set $U$ to the subset $A$ and is denoted by $\mu_{a}(u)$ [16].

To formalize the model for assessing the country's potential using a fuzzy inference system, it will allow taking into account a set of factors and making an integral assessment. The fuzzy inference system reflects the algorithm for constructing fuzzy inferences based on the task of fuzzy conditions. Conditions and conclusions are based on fuzzy statements that make up the rules of fuzzy products and are set [17]: 
(i): $Q ; P ; A \Rightarrow B ; S ; F ; N$,

where $(i)$ - name of the fuzzy product; $Q$ - the scope of fuzzy product implementation; $P$ - condition for using the core of fuzzy products; $A$ - core condition (antecedent); $B$ - core output (consequent); $S$ - method for determining the quantitative value of the truth degree of the conclusion of the core; $F$ - confidence coefficient of fuzzy products; $N$ - postconditions of production.

The set of model rule base can be represented in the form of Table 1 [18].

The structure of the rules of the fuzzy base of products on the left side reflects a combination of conditions that can be combined by the logical conjunction AND:

$$
\begin{aligned}
& \mu_{C}(x)= \\
& =\min \left\{\mu_{A}(x) ; \mu_{B}(x)\right\} \\
& (\forall x \in X) .
\end{aligned}
$$

In general, the rule of fuzzy product base will look like:

$$
\begin{aligned}
& \text { RULE <\# }>\text { : IF " } x_{1} \in X_{n} " \\
& \text { AND " } x_{2} \in X_{n} " T N E N \\
& " y_{1} \in Y_{n} " .
\end{aligned}
$$
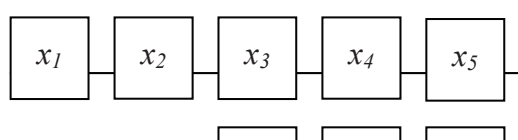

- staff turnover rate $-x_{12}$;

- cultural and educational - $y_{3}$;

- prestige of vocational education $-x_{13}$;

- level of investment of companies in personnel education $-x_{14}$;

- autonomy of educational institutions $-x_{15}$.

The structure of the model for assessing the potential of the country implementing dual education includes three models: economic model, political, cultural and educational. An integrated assessment of the country's potential will look like:

$$
\gamma=f\left(y_{1}, y_{2}, y_{3}\right) .
$$

The structure of the model for assessing the potential for introducing dual education is shown in Fig. 1.
Taking into account the measures that the state (with advanced dual education) takes to restore the demand and supply for places of apprenticeship, it is possible to determine the conditions on which the implementation of dual education in the country depends. The specificity of the dual form of education determines the factors on which the success of implementation depends. The integrative nature of dual education is at the intersection of three spheres (determining groupings of factors): economic, political and cultural-educational.

Tahle 1

Fuzzy model rule base

\begin{tabular}{|c|c|c|c|c|c|c|c|c|c|}
\hline No. & \multicolumn{4}{|c|}{ Input variables } & \multicolumn{4}{c|}{ Dutput variables } & Weights \\
\hline$R_{1}$ & $x_{1}^{(1)}$ & $x_{1}^{(2)}$ & $\ldots$ & $x_{1}^{(n)}$ & $y_{1}^{(1)}$ & $y_{1}^{(2)}$ & $\ldots$ & $y_{1}^{(s)}$ & $\omega_{1}$ \\
\hline$R_{2}$ & $x_{2}^{(1)}$ & $x_{2}^{(2)}$ & $\ldots$ & $x_{2}^{(n)}$ & $y_{1}^{(1)}$ & $y_{2}^{(2)}$ & $\ldots$ & $y_{2}^{(s)}$ & $\omega_{2}$ \\
\hline$\ldots$ & $\ldots$ & $\ldots$ & $\ldots$ & $\ldots$ & $\ldots$ & $\ldots$ & $\ldots$ & $\ldots$ & $\ldots$ \\
\hline$R_{m}$ & $x_{(m)}^{(n)}$ & $x_{(m)}^{(n)}$ & $\ldots$ & $x_{(m)}^{(n)}$ & $y_{(m)}^{(s)}$ & $y_{(m)}^{(s)}$ & $\ldots$ & $y_{(m)}^{(s)}$ & $\omega_{m}$ \\
\hline
\end{tabular}

Models and their factors that influence the adoption of the dual form of education:

- economic model $-y_{1}$;

- level of investment attractiveness $-x_{1}$;

- the average level of salaries in the professional sec-

tor $-x_{2}$;

- youth unemployment rate $-x_{3}$;

- youth employment rate $-x_{4}$;

- tax burden on companies - $x_{5}$;

- level of the shadow labor market $-x_{6}$;

- level of competition in the country $-x_{7}$;

- political $-y_{2}$;

- share of GDP spending on education $-x_{8}$;

- level of influence of trade unions - $x_{9}$;

- level of influence of employers' organizations $-x_{10}$;

- level of corruption $-x_{11}$;
6.3. Modeling results. The factors that make up the mathematical model represent linguistic variables with corresponding terms. The model was evaluated using the Mamdani algorithm in the Matlab software environment. To display the membership function, a trapezoidal representation was used. The input values were evaluated through the analysis of expert opinions and the use of statistical databases (for 2018 and the latest updated data):

- State Statistics Service of Ukraine [19];

- Eurostat [20];

- Organization for Economic Co-operation and Development (OECD) [21];

- International Business Compass (BDO) [22];

- PwC Paying Taxes [23];

- WEF The Global Competitiveness Report [24];

- Corruption Perceptions Index (CPI) [25];

- Mercer Consulting [26].

Linguistic variables, depending on the specifics of the designated factor, were divided from 3 to 5 terms. The definitions of terms indicate the level of influence of a linguistic variable on the integration assessment of the model and are: L (low), BA (below average), A (average), AA (above average), H (high).

The result of fuzzification of the fuzzy inference model for assessing the potential of the country implementing dual education is presented in Table 2. Data are shown in points and percentages. A fragment of the rules for the model of economic potential is presented in Fig. 2.

As a result of the modeling, the assessment of the economic model is $y_{1}=64.1$ (AA), political $y_{2}=38(\mathrm{BA})$, and cultural and educational $y_{3}=53.9(\mathrm{~A})$. The integral estimate is $y=52.1$ (A). As can be seen from the obtained results, the political component model refers to the term below the average, this value is caused by the indicators of the index promoting corruption, the degree of influence of trade unions and a high level of staff turnover. 
Input indicators of the potential assessment model

\begin{tabular}{|c|c|c|c|c|}
\hline$x_{1}$ & $x_{2}$ & $x_{3}$ & $x_{4}$ & $x_{5}$ \\
\hline A (50-60) & H (10000 с. u. <) & A $(15-25 \%)$ & A (25-35 \%) & L (80-100) \\
\hline 45.27 & 9200 с. u. & $17.9 \%$ & $27.60 \%$ & $x_{9}$ \\
\hline$x_{6}$ & $x_{7}$ & $x_{8}$ & L (1-30) & A (40-60) \\
\hline A (20-25 \%) & A (45-55) & H (6-8 \%) & 30 & 60 \\
\hline $21.6 \%$ & $45.6 \%$ & $6.7 \%$ & $x_{14}$ & $x_{15}$ \\
\hline$x_{11} \%$ & $x_{12}$ & $x_{13}$ & A (3.5-4) & A (40-60) \\
\hline AA (30-40) & H (20 <) & A (40-50 \%) & 3.8 & 55 \\
\hline 32 & 23 & $35.7 \%$ & & \\
\hline
\end{tabular}

12. If $(X 1$ is $B)$ and $(X 2$ is $B)$ and $(X 3$ is $H)$ and $(X 4$ is $B)$ and $(X 5$ is $H)$ and $(X 6$ is $H)$ and $(X 7$ is $B)$ then (Y1 is $B)(1)$

13. If $(X 1$ is $B C)$ and $(X 2$ is $B)$ and $(X 3$ is $H)$ and $(X 4$ is $B)$ and $(X 5$ is $H)$ and $(X 6$ is $H)$ and $(X 7$ is $B C)$ then (Y1 is $B)$ (1)

14. If $(X 1$ is $C)$ and $(X 2$ is $B)$ and $(X 3$ is $C)$ and $(X 4$ is $C)$ and $(X 5$ is $H)$ and $(X 6$ is $C)$ and $(X 7$ is $C)$ then (Y1 is $B C)(0.7)$

15. If ( $X 1$ is $C)$ and $(X 2$ is $B)$ and $(X 3$ is $C)$ and ( $X 4$ is $C)$ and $(X 5$ is $H)$ and $(X 6$ is $C)$ and (X7 is $C)$ then (Y1 is $C)(0.3)$

Fig. 2. Fragment of rules created in the Matlab software environment

In particular, a high rate of staff turnover may indicate insufficiently regulated labor legislation. The organizations of employers mainly represent the interests of large business due to the uneven representation of organizations at the national level of social dialogue. These imbalances between the influence of trade unions and employers' organizations can adversely affect the introduction of dual education. However, the high degree of government spending on education indicates the priority of education for the state. Thus, the imbalance of the social dialogue of the introduction of dual education depends largely on the strength of the influence and initiative of the state.

6.4. Discussions of the results. Assessing the potential for introducing dual education in Ukraine is a complex model with complex formalization. The apparatus of fuzzy logic is a tool that allows to solve complex formalization problems, where the degree of membership can be converted from a quantitative to a qualitative quantity and vice versa, resulting in numerical results. The resulting integral assessment $=52.1$, which corresponds to the average value, indicates the presence of Ukraine's potential in vocational education. In particular, it is worth noting the level of culture of vocational education in Ukraine, that is, the prestige of vocational education is $\mathrm{y}_{13}$, which is the average value in the fuzzy model among European countries, while it should be noted that the dynamics of the indicator has been at its minimum value since the independence of Ukraine [19]. The potential of the professional sector can be attributed to the high value of the indicator of the level of wages. The high value of the GDP expenditures on education (one of the highest among European countries) indicates the state's intentions to reform the educational sector. The imbalance between the level of influence of trade unions and employers' organizations is a negative aspect, since big business has a large share of the job market for apprenticeship places in the labor market, therefore, the state should become a subject of negotiations on behalf of students to eliminate the monopolization of the negotiation process (which is characteristic, in particular, for the Swiss model of appren- ticeship). The average rate of investment in staff education is a positive aspect, which indicates the willingness of companies to invest in education. The average level of youth employment also indicates the readiness of students to combine work and education in the framework of dual education. It should also be noted the integrated assessment of the economic model is $y_{1}=64.1$ and refers to the term «above average».

Taking into account the cultural background of vocational education and the readiness of large business representatives to invest in dual education, the success of the introduction of dual education depends on the reforms of the state and its readiness to take into account the interests of all interested parties.

6.5. Reasons for the introduction of dual education in Ukraine. The introduction of the dual form of education in Ukraine is due to the problems that are inherent in the domestic educational sphere and in the labor market. Ukraine belongs to countries with economies in transition, in addition, the socialist past has left an imprint on the educational sphere. The number of vocational schools in 1990 amounted to 1246 institutions, which graduated 376.7 thousand graduates this year. Already in 2017, the number of educational institutions totaled 756 vocational schools, 141.3 thousand skilled workers graduated (trained) [19]. The dynamics of a decrease in the number of educational institutions and the graduation of workers is a consequence of economic changes, evolution from the command economy to a market economy. As a result of the spread of the market economy, privatized enterprises began to lose touch with educational institutions due to the weakening of state regulation. At the same time, the opposite trend is observed in the higher education sector. So, from 1990 to 2017 the number of higher education institutions and graduates has almost doubled from 149 to 289 and 136.9 to 359.9 thousand. However, this growth in graduates does not indicate the quality of education. Thus, according to World Bank studies, 4 out of 10 firms surveyed in four key sectors stated that the skills that employees possess and 
those that are necessary to achieve business goals do not match [27]. Also, according to the data of the State Employment Service as of September 2018, every second unemployed person has a higher education, every third person has a vocational education [28]. Unemployed, unemployed after graduation, as of the first half of 2018, there were 129,600 people. So, the statistics indicate the problems that are inherent in the educational sector in Ukraine. The decline in the quality of education is a consequence of complex problems, but the main drawback of the Ukrainian system is the loss of connection between the educational system and the economy. Outdated equipment with which students are trained, inappropriate practice, low attendance of full-time students by students - these factors indicate the need to expand the education system, education at the workplace, that is, a dual form of education.

An important issue is the introduction of dual education at all levels of education. One of the reasons for the massification of higher education in Ukraine is the lack of a connection between the economy and the educational sector. Reinforcing higher education with practical education will make it possible to educate and evaluate students as subjects of market relations. As a result, the introduction of dual education at the highest educational level will even out the imbalances in the professional sector.

\section{SWOT analysis of research results}

Strengths. The strengths of the research include the complexity of the problem. Complexity consists in systematizing the factors of the model for assessing potential into subsystems with the subsequent derivation of intermediate integral estimates. Interim assessments eventually led to a general assessment of the potential for introducing dual education in Ukraine.

Weaknesses. The weaknesses of research include the need for education the fuzzy inference system. Optimal estimates are achieved by conducting a sufficient number of system runs.

Opportunities. Quantitative results of research are indicators of integrated assessment and factors indicators, which are components of the subsystem and the entire model. Influence on the indicators of the model changes the indicator of integrated assessment. Thus, the application of the model provides a set of indicators of the state (affecting the functioning of the dual form of education and its implementation) of the country and opens up opportunities for reforms (leverage) in the relevant sectors, and serves as an analytical tool. The study is important from the point of view of the international transfer of dual education, as it provides opportunities for assessing the potential of any country wishing to introduce a dual form of education.

Threats. A negative factor is the dependence on the state's decision on the implementation and implementation of necessary reforms. The issue of education is a state priority. Therefore, given the very concept, the concept of education and the goals of the subsystems, as well as the system of dual education of its education, development, regulation is initiated by the state and its support. The dual education system is a state creation; therefore, its success depends on the willingness and power of the state's influence.

\section{Conclusions}

1. An analysis of the reasons for the introduction of dual education in Ukraine is highlighted through the disclosure of the dynamics of the development of the educational sector with the trend of higher education dominating. The number of vocational schools in 1990 amounted to 1246 institutions, which graduated 376.7 thousand graduates this year. Already in 2017, the number of educational institutions totaled 756 vocational schools, 141.3 thousand skilled workers graduated (trained). At the same time, the opposite trend is observed in the higher education sector. So, from 1990 to 2017 the number of higher education institutions and graduates has almost doubled from 149 to 289 and 136.9 to 359.9 thousand, respectively. However, this fact does not speak about the quality of higher education. Thus, according to a World Bank study, 4 out of 10 firms surveyed in four key sectors reported a mismatch between the skills that workers possess and those that are necessary to achieve business goals. Also, according to the data of the State Employment Service as of September 2018, every second unemployed person has a higher education, every third person has a vocational education. Unemployed, unemployed after graduation, as of the first half of 2018 , there were 129,600 people. These facts indicate the need to reform the educational sector, in particular through the restoration of the connection of the education system with the labor market, economy, by introducing a dual form of education.

2. An analysis of the foreign experience of dual education revealed aspects of the functioning of this type of education, in particular the selection of a collective type, which is based on dialogue between interested parties. This allows to determine the model and the interaction sides. The history of the development of the German model of dual education shows that in the system of dual education, the dominant side in the educational process is companies. It can be stated that the vital activity of the system depended on a collective agreement between the state and companies. Even in the days of only inhouse education of craft guilds, the state decided that their membership was mandatory. The segmented type of interaction between education and business is focused on obtaining narrow skills by students and the refusal to invest the company in general education to expand the transferability of qualifications. The reasons for the refusal of companies to invest in general education, in particular, include the problem of the payback of education and the enticement of qualified personnel by competitors. Thus, the state should be a full-fledged participant in the negotiation process in dual education, providing guarantees of employment for students and providing financial benefits to companies (through subsidies, reducing the tax burden). The complexity and complexity of the concept of dual education required clarification of this definition. A refined definition is proposed: the dual form of education is education system, the implementation of which occurs through activities in the workplace. The constituent subsystems of which are education in a company (work environment) and in an educational institution, in which the fundamental relationship between learning locations is provided by information technology.

3. The analysis of foreign practices of dual learning has allows to formalize a model of a fuzzy derivation of 
the assessment of the potential for implementing dual learning. As a result, the model consists of the following subsystems and their factors:

- economic model (level of investment attractiveness, average level of wages in the professional sector, youth unemployment rate, youth employment rate, tax burden on companies, level of shadow labor market, level of competition in the country);

- political (the share of GDP spending on education, the level of influence of trade unions, the level of influence of employers' organizations, the level of corruption, the level of staff turnover);

- cultural and educational (the prestige of vocational education, the level of companies' investments in staff education, the autonomy of educational institutions). 4. As a result of the simulation, the assessment of the economic model is $y_{1}=64.1$ (AA), political $y_{2}=38$ (BA), cultural and educational $y_{3}=53.9$ (A). The integral assessment is $y=52.1$ (A). The resulting integral assessment $y=52.1$, which corresponds to the average value, indicates the presence of Ukraine's potential in vocational education. In particular, it is worth noting the level of culture of vocational education in Ukraine, that is, an indicator of the prestige of vocational education $y_{13}$, which is the average value in the fuzzy model among European countries. It should be noted that the dynamics of the indicator has been at its minimum value since the independence of Ukraine. The potential of the professional sector can be attributed to the high value of the indicator of the level of wages. The high value of the GDP expenditures on education (one of the highest among European countries) indicates the state's intentions to reform the educational sector. It should also be noted the integrated assessment of the economic model is $y_{1}=64.1$ and refers to the term «above average». The imbalance between the level of influence of trade unions and employers' organizations is a negative aspect, since big business occupies a large share of the job market for apprenticeship places in the labor market. Therefore, the state should become the subject of negotiations on behalf of students to eliminate the monopolization of the negotiation process (which is typical, in particular for the Swiss model of apprenticeship).

\section{References}

1. Rojko, A. (2017). Industry 4.0 Concept: Background and Overview. International Journal of Interactive Mobile Technologies, 11 (5), 77-90. doi: http://doi.org/10.3991/ijim.v11i5.7072

2. Approval of the Concept for the Development of the Digital Economy and Society of Ukraine for 2018-2020 and approval of the plan of measures for its implementation (2018). Order of the Cabinet of Ministers of Ukraine No. 67-p. 17.01.2018. Available at: http://zakon2.rada.gov.ua/laws/show/67-2018-\%D1\%80

3. Gessler, M. (2017). The lack of collaboration between companies and schools in the German dual apprenticeship system: Historical background and recent data. International Journal for Research in Vocational Education and Training (IJRVET), 4 (2), 164-195. doi: http://doi.org/10.13152/IJRVET.4.2.4

4. Thelen, K. A., Busemeyer, M. R. (2008). From collectivism towards segmentalism: Institutional change in German vocational training (No. 08/13). MPIfG discussion paper. Available at: https://www.mpifg.de/pu/mpifg dp/dp08-13.pdf

5. Deissinger, T., Hellwig, S. (2005). Apprenticeships in Germany: modernising the Dual System. Education + Training, 47 (4/5), 312-324. doi: http://doi.org/10.1108/00400910510601896

6. Gonon, P. (2005). Challenges in the Swiss vocational education and training system. Berufs-und Wirtschaftspädagogik online, 7.
7. Eichhorst, W., Rodríguez-Planas, N., Schmidl, R., Zimmermann, K. F. (2012). A roadmap to vocational education and training systems around the world. Available at: http://repec. iza.org/dp7110.pdf

8. Euler, D. (2013). Germany's dual vocational training system a model for other countries? doi: http://doi.org/10.11586/2017022

9. Langthaler, M. (2015). The transfer of the Austrian dual system of vocational education to transition and developing countries: An analysis from a developmental perspective (No. 53). Working Paper, Austrian Foundation for Development Research (ÖFSE). Available at: https://www.oefse.at/fileadmin/content/Downloads/Publikationen/Workingpaper/WP53 dual system.pdf

10. Modláné, I. G. (2015). With Dual Training in the World of Work. Budapest: Hungarian Chamber of Commerce and Industry, 56.

11. On Approval of the Concept of Training of Specialists in the Dual Form of Education Regulation (2018). Cabinet of Ministers of Ukraine; Concept No. 660-p. 09.09.2018. Available at: https://zakon.rada.gov.ua/laws/show/660-2018-r

12. Lerman, R. I. (2017). Why Firms Do and Don't Offer Apprenticeships. Vocational Education and Training in Times of Economic Crisis, 305-320. doi: http://doi.org/10.1007/978-3319-47856-2_16

13. Acemoglu, D., Pischke, J. (1999). Beyond Becker: Training in Imperfect Labour Markets. The Economic Journal, 109 (453), 112-142. doi: http://doi.org/10.1111/1468-0297.00405

14. Koudahl, P. D. (2010). Vocational education and training: dual education and economic crises. Procedia - Social and Behavioral Sciences, 9, 1900-1905. doi: http://doi.org/10.1016/ j.sbspro.2010.12.421

15. Zadeh, L. A. (1965). Fuzzy sets. Information and Control, 8 (3), 338-353. doi: http://doi.org/10.1016/s0019-9958(65)90241-x

16. Zade, L. (1976). The concept of a linguistic variable and its application to making approximate decisions. Moscow: World, 167.

17. Leonenkov, A. V. (2005). Fuzzy Modeling in MATLAB and fuzzy TECH. Saint Petersburg: BHV-Petersburg, 736.

18. Rogatinsky, R. M, Garmatiy, N. M. (2015). Mathematical Methods of Market Economy for Cybernetics Specialists. Ternopil: Aston, 206.

19. Official site of the State Statistics Service of Ukraine. Available at: http://www.ukrstat.gov.ua/

20. Official site of Eurostat. Available at: https://ec.europa.eu/ eurostat/data/database

21. Official site of Organisation for Economic Co-operation and Development OECD. Available at: https://data.oecd.org

22. BDO international business compass (2018). Available at: https:/ www.bdo.global/en-gb/insights/bdo-germany/bdo-internationalbusiness-compass-2018

23. Paying Taxes (2018). PwC Global. Available at: https://www.pwc. $\mathrm{com} / \mathrm{gx} / \mathrm{en} /$ paying-taxes/pdf/pwc_paying_taxes_2018_full_report.pdf

24. WEF Global Competitiveness Report (2018). Available at: http:// reports.weforum.org/global-competitiveness-report-2018/competitiveness-rankings $/$ \#series = GCI4.C.07.01

25. Transparency International. Corruption perception index (2018). Available at: https://www.transparency.org/cpi2018

26. Gutman, P. (2016). Tackling trends in turnover. Mercer Consulting. Available at: https://www.mercer.com/content/dam/ mercer/attachments/global/webcasts/gl-2016-webcast-talenttackling-trends-in-turnover-mercer.pdf

27. Carpio, D. X., Kupets, O., Muller, N., Olefir, A. (2017). Skills for a Modern Ukraine. Washington: Overview booklet. World Bank, License: Creative Commons Attribution CC BY 3.0 IGO. Available at: http://wbgfiles.worldbank.org/documents/hdn/ ed/saber/supporting_doc/Background/WFD/SABER_WFD_ Background Skills for a modern Ukraine.pdf

28. Official Website of the State Employment Service. Available at: https://www.dcz.gov.ua

Lechachenko Taras, Postgraduate Student, Department of Cybersecurity, Ternopil Ivan Puluj National Technical University, Ukraine, e-mail: Taras5a@ukr.net, ORCID: http://orcid.org/00000003-1185-6448 